\title{
Self-medication practices and associated factors among households at Gondar town, Northwest Ethiopia: a cross-sectional study
}

\author{
Ebabu Jember ${ }^{1}$, Amsalu Feleke ${ }^{2}$, Ayal Debie ${ }^{2^{*}}$ and Geta Asrade ${ }^{2}$
}

\begin{abstract}
Objective: Self-medication practice is the selection and use of medicines by individuals or a member of the individual's family without physician's order to treat self-recognized or self-diagnosed conditions. It is highly prone to inappropriate use and wastage of resources, increase drug resistance pathogens and adverse reactions. Therefore, this study aimed to assess self-medication practices and associated factors among households at Gondar town, Northwest Ethiopia.

Results: This community based cross-sectional study was conducted among households at Gondar town from March to June, 2018. The overall prevalence of self-medication practices among households at Gondar town were $50.2 \%$. The odds of self-medication practices among unmarried participants ( $A O R=3.12 ; 95 \% \mathrm{Cl} 2.35,5.34)$, influenced by peer $(A O R=3.58 ; 95 \% \mathrm{Cl} 2.89,7.28)$, poor perceived quality of health care services $(A O R=4.67 ; 95 \% \mathrm{Cl} 2.56,7.96)$ and access to pharmacy ( $A O R=2.32 ; 95 \% \mathrm{Cl} 1.65,6.76)$ were higher compared with their counterparts. In the contrary, the lesser odd was observed among knowledgeable participants about medications ( $\mathrm{AOR}=0.27 ; 95 \% \mathrm{Cl} 0.16$, 0.39) compared with non-knowledgeable. Therefore, improving perception of participants about quality of services, conducting awareness creation and managing negative effects of peer may reduce self-medication practices.
\end{abstract}

Keywords: Self-medication practices, Households, Factors, Gondar, Ethiopia

\section{Introduction}

Self-medication (SM) is the selection and use of medicines by individuals or a member of the individual's family without physician's order to treat self-recognized or self-diagnosed conditions [1]. It can help to treat minor ailments that do not require medical consultation and hence reduce the pressure on medical services, particularly in the deprived countries with inadequate health care resources. In a number of developing countries, many drugs are dispensed over the counter without medical direction [2].

Self-medication practices (SMP) is highly prone to inappropriate use and has its own drawbacks resulting

\footnotetext{
*Correspondence: debieayal@gmail.com

2 Department of Health Systems and Policy, Institute of Public Health,

College of Medicine and Health Sciences, University of Gondar,

P.O.Box 196, Gondar, Ethiopia

Full list of author information is available at the end of the article
}

wastage of resources, increase drug resistance pathogens and adverse reactions $[3,4]$. It can also lead to incorrect self-diagnosis, delays in seeking appropriate care, dangerous drug interactions, risk of dependence, drug abuse, incorrect dosage and choice of medication [5, 6]. A systematic review reports indicated that prevalence of SMP was high globally and varies from 32.5 to $81.5 \%$ [7-11] and the average prevalence of SMPs in Ethiopia was also $36.8 \%$ [12].

Nowadays, drug resistance is becoming a worldwide problem, mainly in developing countries as a result of the availability and the use of antibiotics without prescription [13-15]. Accordingly, new forms of resistant pathogens can spread between continents with ease and this considered as "nightmare bacteria" that "pose a catastrophic threat" to people in every country in the world [16].

In many developing countries, antibiotics and potentially habit-forming medicines are easily available in every pharmacy sells without prescription. This together 
with poor awareness and lack of a good primary health care system coupled with cost issues cause the general public to buy drugs from private health institutions and shops without prescription [17].

In spite of this, there is limited literatures and no specific measures designed to address the problem in the country. Therefore, this study aimed to assess self-medication practices and associated factors among households at Gondar town, Northwest Ethiopia.

\section{Main text \\ Methods}

\section{Study design and settings}

A community based cross-sectional study was conducted among households at Gondar town from February to May, 2018. Gondar town is found in the northwest part of Ethiopia and it is 180, and $748 \mathrm{~km}$ far from Bahir Dar (capital city of Amhara region) and Addis Ababa, respectively. Based on the 2007 Central Statistical Agency (CSA) report of Ethiopia, the town had a total population of 400,000. From these, 198,120 (men) and 201,880 (women). The town has also 23 kebeles and 48 health institutions; these are: 1 comprehensive referral hospital, 8 health centers, 1 private general hospital, 15 speciality clinics, 15 medium clinics and 8 primary clinics.

\section{Population and sampling procedure}

All households in Gondar town were the source population, where as households in the selected kebeles of Gondar town were the study population. The sample size was determined using single population proportion formula with an assumption of the prevalence of SMP in Northwest Ethiopia (27.5\%) [18], 95\% Confidence Level (CL), 5\% margin of error, $5 \%$ non-response rate and 2 design effect. The final sample size was 642 . After sample size determination, five kebeles has been selected by using lottery method. Then the total sample size, 642, was proportionally allocated among the five selected kebeles based on the size of the households. The head of the household was our study participants. Accordingly, the interval was determined through dividing the total households to the total sample sizes and the first household was selected through lottery method among households within the first range of interval. Finally, systematic sampling technique was used to select participants.

\section{Data collection tools and procedures}

Interviewer administered structured questionnaire was used for data collection. The questionnaire was developed from reviewing different literatures [19-24]. The questionnaire was first prepared in English, then translated to Amharic and finally back to English by language expertise in order to maintain its consistency. Pre-test was also conducted among 32 households at Bahir Dar town and any ambiguity was modified based on pre-test findings. A total of 6 diploma graduated pharmacy technicians were recruited for data collectors and 3 Bachelor degree graduated pharmacists were recruited for supervisors. A-day training was given for data collectors and supervisors about the basic techniques of the data collection procedures.

\section{Measurements}

Self-medication practice, the outcome variable, was assessed by the selection and use of medicines/drugs by individuals or a member of the individual's family with out physician's order to treat self-recognized or selfdiagnosed conditions in the past 6 months [25]. Accordingly, knowledge of participants about medications was measured by using eight item questions and each item contains $(0=$ no and $1=$ yes $)$ alternatives, and respondents who scored $\geq 50 \%$ of the total knowledge measuring scores were considered as knowledgeable.

\section{Data management and analysis}

Data were entered and analyzed using Epi-Info version 7.1 and SPSS version 20, respectively. Descriptive statistics such as frequencies and percentages were presented using tables, graphs, and texts. Variables with $\mathrm{p}$-value $<0.2$ during bivariable analysis were fitted to multiple logistic regression analysis. Finally, Adjusted Odds Ratio (AOR) with 95\% CI and p-value less than 0.05 were used to determine variables significantly associated with SMPs.

\section{Results}

\section{Socio-demographic and economic characteristics}

A total of 632 participants were participated with a response rate of $98.4 \%$. About $60.8 \%$ of participants were females. $71.4 \%$ of respondents aged $30-45$ years and the mean age of respondents was $36 \pm 11$ SD years. More than two-thirds $(68.5 \%)$ of participants were Orthodox Christians and about $57 \%$ of the respondents were married. About 30\% of participants had less than ETB 1000 (USD 37.7) monthly household income and attended their secondary school. Nearly one-fifth $(18.5 \%)$ of the participants were government employee and more than $20 \%(21.4 \%)$ of participants had five or more family members (Table 1).

\section{Self-medication practices}

The prevalence of SMP among households in the past 6 months at Gondar was $50.2 \%$. more than $60 \%$ (60.9\%) of the household had history of SMPs within their family members in the town, but they didn't remember the name of the drug. About $13.2 \%$ of the participants 
Table 1 Socio-demographic and economic characteristics of the respondents at Gondar town, Northwest Ethiopia, 2018

\begin{tabular}{|c|c|c|}
\hline Variables & Frequency & Percent (\%) \\
\hline \multicolumn{3}{|l|}{ Sex of participants } \\
\hline Male & 248 & 39.2 \\
\hline Female & 384 & 60.8 \\
\hline \multicolumn{3}{|l|}{ Age in years } \\
\hline$<30$ & 70 & 11.1 \\
\hline $30-45$ & 451 & 71.4 \\
\hline$\geq 45$ & 111 & 17.6 \\
\hline \multicolumn{3}{|l|}{ Religion } \\
\hline Orthodox & 433 & 68.5 \\
\hline Muslim & 181 & 28.6 \\
\hline Protestant & 18 & 2.9 \\
\hline \multicolumn{3}{|l|}{ Marital status } \\
\hline Single & 267 & 42.2 \\
\hline Married & 365 & 57.8 \\
\hline \multicolumn{3}{|l|}{ Educational status } \\
\hline Unable to read and write & 113 & 17.9 \\
\hline Primary school & 166 & 26.3 \\
\hline Secondary school & 193 & 30.5 \\
\hline College diploma and above & 160 & 25.3 \\
\hline \multicolumn{3}{|l|}{ Monthly household income } \\
\hline ETB $<1000(<$ USD 37.7) & 189 & 29.9 \\
\hline $\mathrm{ETB} \geq 1000(\geq$ USD 37.7) & 443 & 70.1 \\
\hline \multicolumn{3}{|l|}{ Family size } \\
\hline$<5$ & 497 & 78.6 \\
\hline$\geq 5$ & 135 & 21.4 \\
\hline \multicolumn{3}{|l|}{ Occupation } \\
\hline Govt employee & 117 & 18.5 \\
\hline Merchant & 299 & 47.3 \\
\hline Daily laborer & 103 & 16.3 \\
\hline Others & 113 & 17.9 \\
\hline
\end{tabular}

encounter some drug adverse reactions and more than $40 \%$ (43.2\%) had checked the expiry date of the drug before they use. Similarly, almost half (49.5\%) were concerned that increasing the dose of the drug can be hazardous for health. About $46 \%$ of respondents had access to pharmacy and more than half (56\%) of participants were influenced by their peer/s (Table 2).

\section{Source of information about SMPs}

More than one-third (35.3\%) of the sources of information for their households about medication practices were pharmacy professionals and previous experience was also the sources of information for around $30 \%$ of the participants. On the other hand, one-third (67.8\%) of the respondents had bought the drugs for SMPs were private drug stores followed by $11.7 \%$ private clinic. About $45.4 \%$ participants were knowledgeable about medications, one-fifth (22.2\%) of respondents had good perceived quality of governmental health care services and $42.4 \%$ perceived the costs of SMs was cheap (Additional file 1: Table S1).

\section{Reasons and common symptoms for SMPs}

Participants reported that the reasons for their households SMPs were severity of illnesses (44.8\%), emergency cases $(35.3 \%)$, reducing medical cost $(17 \%)$, lack of trust by the prescribers (4.1\%) and for saving time (5.1\%) (Additional file 2: Fig S1).

The common symptoms/illnesses that prompted SMs among participants who had practiced self-medications were headache $(63.1 \%)$, RTIs (cough, cold/flu) (30.9\%), fever (18.9\%), GIT infections (diarrhea, vomiting) (38.9\%) and dysmenorrhea (7.6\%) (Additional file 3: Fig S2).

\section{Factors associated with SMPs}

Binary logistic regression model was used for analysis. AOR with 95\% CI and p-value less than 0.05 were used to determine variables associated with SMPs. The odds of SMPs was higher among unmarried $(\mathrm{AOR}=3.12 ; 95 \% \mathrm{CI}$ $2.35,5.34)$, influenced by peer pressure $(\mathrm{AOR}=3.58$; $95 \%$ CI $2.89,7.28)$, access to pharmacy $(\mathrm{AOR}=2.32 ; 95 \% \mathrm{CI}$ $1.65,6.76)$ and poor perceived quality of governmental health care services (AOR $=4.67 ; 95 \% \mathrm{CI} 2.56,7.96) \mathrm{com}$ pared with that of their counterparts. On the other hand, lesser odds of SMP was observed among knowledgeable participants about medications (AOR $=0.27 ; 95 \% \mathrm{CI}$ $0.16,0.39$ ) than that of non-knowledgeable (Table 3).

\section{Discussion}

This study was designed to assess the prevalence of SMPs and associated factors among households at Gondar town, Northwest Ethiopia. In our survey, prevalence of SMPs in the past 6 months was $52.2 \%$. The finding was higher than studies done at University of Gondar (38.5\%) [19], Mekelle (43.24\%) [20], Meket district (35.9\%) [26], Nekemte (36.7\%) [27], Northwest Ethiopia (27.5\%) [18], Puducherry, India (11.9\%) [28], Saudi Arabia (35.4\%) [29] and Haman dan province, Iran (35.4\%) [30]. However, it was lower than studies done in Harar (57.8\%) [31], Addis Ababa (72.8\%) [21], Sri Lankan (60.8\%) [32], Pune (87.5\%) [33], Belgrade, Serbia (79.9\%) [34], Oman University (94\%) [25], Pokhara, Nepal (59\%) [22], Italy (69.2\%) [35], Barabanki (69.6\%) [36], Delhi, India (92.8\%) [37], Turkey (63.4\%) [38], private University Malaysia (77.6\%) [39], Mbeya, Tanzania (55.7\%) [40], Gulbarga Karnataka, India (88.2\%) [41], Karachi, Pakistan (76\%) [24] and Egypt (62.9\%) [42]. This variation may be due to the differences in social determinants of health, beliefs, culture 


\begin{tabular}{|c|c|c|}
\hline Variables & Frequency & Percent (\%) \\
\hline \multicolumn{3}{|c|}{ Self-medication practices } \\
\hline No & 315 & 49.8 \\
\hline Yes & 317 & 50.2 \\
\hline \multicolumn{3}{|c|}{ Did you remember the name of the drug? } \\
\hline No & 193 & 60.9 \\
\hline Yes & 124 & 39.1 \\
\hline \multicolumn{3}{|c|}{$\begin{array}{l}\text { Did you encounter any adverse drug reaction during self-medication } \\
\text { practices? }\end{array}$} \\
\hline No & 275 & 86.8 \\
\hline Yes & 42 & 13.2 \\
\hline \multicolumn{3}{|c|}{ Did you check the expiry date of the drugs before use? } \\
\hline No & 180 & 56.8 \\
\hline Yes & 137 & 43.2 \\
\hline \multicolumn{3}{|c|}{$\begin{array}{l}\text { Did you have any concern that increasing drug dose can be hazardous for } \\
\text { health? }\end{array}$} \\
\hline No & 160 & 50.5 \\
\hline Yes & 157 & 49.5 \\
\hline \multicolumn{3}{|c|}{$\begin{array}{l}\text { Did you ever check the instructions/leaflets within the drugs package dur- } \\
\text { ing self-treatment? }\end{array}$} \\
\hline No & 232 & 36.7 \\
\hline Yes & 85 & 13.4 \\
\hline \multicolumn{3}{|c|}{ Access to pharmacy } \\
\hline No & 341 & 54.0 \\
\hline Yes & 291 & 46.0 \\
\hline \multicolumn{3}{|c|}{ Peer pressure } \\
\hline No & 278 & 44.0 \\
\hline Yes & 354 & 56.0 \\
\hline
\end{tabular}

of the population, and variation on recall periods used in each study.

Our finding indicated that the odds of SMPs among unmarried participants were 3.12 times higher than the odds of married participants. This finding was consistent with the studies conducted in Meket district, Ethiopia [27] and Udupi Taluk, southern India [43]. This might be so because unmarried participants could be influenced by peer pressure. The odds SMPs among households who were influenced by peer pressure were 3.58 times higher than that of the respondents who didn't influence by their peers. This study was in line with other studies done in Meket [27], China [44] and Uganda [45]. The possible explanation might be due to the source of information for peers/friends might be the same. Similarly, they may have similar life experience and can also share their own previous practices between them. This could also work in the case of self-medications.

Our study report also indicated that the odds of SMPs among knowledgeable participants were lesser by $73 \%$ compared with their counterparts. This might be due to knowledgeable community members may fear the bad adverse reactions self-medications. Accordingly, the odds of SMPs among participants who had poor perceived quality of health care services in the governmental health care facilities were 4.67 times higher than respondents who had good perceived quality of health care. The possible explanation might be so because participants who had poor perceived quality health care services may decide that the role of physician's diagnosis is not significant for treating their health problems.

In this study, the odds of SMPs among respondents who had an access to pharmacy were 2.32 times higher compared with the participants who had no access. This finding was supported by studies conducted in Meket, Ethiopia [27], China [44], southern India [43] and Nigeria [46]. The possible justification might be due to the inability of the participants to afford health care fees and lack of time to consult health care professionals. Therefore, improving perception of participants about the quality of health care services, awareness creation and managing peer pressure may reduce self-medication practices.

\section{Limitations}

- This study was conducted in urban setting which didn't show the practices of the rural area.

- The study was assessing only about modern medicines which did not include practices of traditional medications that might be under estimate our findings in the study area. 
Table 3 Multiple logistic regression analysis for factors associated with SMPs at Gondar town, Northwest Ethiopia, 2018

\begin{tabular}{|c|c|c|c|c|c|}
\hline \multirow[t]{2}{*}{ Variables } & \multicolumn{2}{|c|}{ Self-medication practices } & \multirow[t]{2}{*}{ COR $(95 \% \mathrm{Cl})$} & \multirow[t]{2}{*}{ AOR $(95 \% \mathrm{Cl})$} & \multirow[t]{2}{*}{ p-value } \\
\hline & Yes & No & & & \\
\hline \multicolumn{6}{|l|}{ Sex of participants } \\
\hline Male & 127 & 121 & 1 & 1 & \\
\hline Female & 190 & 194 & $0.93(0.68,1.28)$ & $0.75(0.53,1.51)$ & 0.51 \\
\hline \multicolumn{6}{|l|}{ Age in years } \\
\hline$<30$ & 40 & 30 & 1 & 1 & \\
\hline $30-45$ & 210 & 241 & $0.65(0.39,1.09)$ & $0.51(0.25,1.25)$ & 0.18 \\
\hline$\geq 45$ & 67 & 44 & $1.14(0.62,2.10)$ & $1.63(0.38,3.12)$ & 0.46 \\
\hline \multicolumn{6}{|l|}{ Marital status } \\
\hline Single & 157 & 110 & $1.83(1.33,2.52)$ & $3.12(2.35,5.34)^{*}$ & 0.01 \\
\hline Married & 160 & 205 & 1 & 1 & \\
\hline \multicolumn{6}{|l|}{ Peer pressure } \\
\hline No & 82 & 196 & 1 & 1 & \\
\hline Yes & 235 & 119 & $4.72(3.36,6.63)$ & $3.58(2.89,7.28)^{*}$ & 0.001 \\
\hline \multicolumn{6}{|l|}{ Monthly household income } \\
\hline$<$ ETB $1000(<$ USD 37.7) & 107 & 82 & 1 & 1 & \\
\hline$\geq$ ETB $1000(\geq$ USD 37.7) & 210 & 233 & $0.69(0.49,0.97)$ & $0.52(0.34,1.17)$ & 0.32 \\
\hline \multicolumn{6}{|l|}{ Access to pharmacy } \\
\hline No & 223 & 118 & 1 & 1 & \\
\hline Yes & 199 & 92 & $4.09(2.93,5.70)$ & $2.32(1.65,6.76)^{*}$ & 0.001 \\
\hline \multicolumn{6}{|l|}{ Family size } \\
\hline$<5$ members & 255 & 242 & 1 & 1 & \\
\hline$\geq 5$ members & 62 & 73 & $0.81(0.55,1.18)$ & $0.62(0.37,1.39)$ & 0.25 \\
\hline \multicolumn{6}{|c|}{ Perceived quality of health care } \\
\hline Good & 54 & 86 & 1 & 1 & \\
\hline Poor & 263 & 229 & $1.83(1.25,2.68)$ & $4.67(2.56,7.96)^{*}$ & 0.001 \\
\hline \multicolumn{6}{|l|}{ Perceived cost } \\
\hline Expensive & 181 & 183 & 1 & 1 & \\
\hline Cheap & 136 & 132 & $1.04(0.76,1.43)$ & $2.17(0.64,5.84)$ & 0.67 \\
\hline \multicolumn{6}{|l|}{ Knowledge } \\
\hline Not knowledgeable & 249 & 96 & 1 & 1 & \\
\hline Knowledgeable & 68 & 219 & $0.12(0.08,0.17)$ & $0.27(0.16,0.39)^{*}$ & 0.01 \\
\hline
\end{tabular}

* Significant at $p$-value $<0.05$

- The study might also prone to recall bias as a result of self-reporting of the participants for their last 6 months experiences.

\section{Additional files}

Additional file 1: Table S1. Sources of information and drugs for SMPS among households at Gondar town, Northwest Ethiopia, 2018.

Additional file 2: Fig. S1. Reasons for self-medication practices among households at Gondar town, Northwest Ethiopia, 2018 ( $n=317$ ).

Additional file 3: Fig. S2. Common symptoms/illnesses that prompted self-medications among households at Gondar town, Northwest Ethiopia, $2018(n=317)$

\section{Abbreviations}

AOR: Adjusted Odds Ratio; Cl: Confidence Interval; COR: Crude Odds Ratio; GIT: Gastro-Intestinal Tract; RTIs: Respiratory Tract Infections; SM: Self-Medications; SMP: Self-Medication Practice; WHO: World Health Organization.

\section{Authors' contributions}

EJ was involved in the conception, design, analysis, interpretation, report and manuscript writing. AF, AD and GA also involved in the design, analysis, interpretation of the data, and manuscript writing. All authors read and approved the final manuscript.

\section{Author details}

${ }^{1}$ Department of Pharmacy, College of Medical and Business, Addis Ababa, Ethiopia. ${ }^{2}$ Department of Health Systems and Policy, Institute of Public Health, College of Medicine and Health Sciences, University of Gondar, P.O.Box 196, Gondar, Ethiopia. 


\section{Acknowledgements}

Authors would like to thanks for Institute of Public Health, College of Medicine and Health sciences, University of Gondar for giving an opportunity to study in this area. In addition, our gratitude goes to Gondar town health office staff members for their co-operation by providing the necessary information. Finally, we would like to thank the study participants and data collectors.

\section{Competing interests}

The authors declared that they have no competing interests.

\section{Availability of data and materials}

Data is available from the corresponding authors.

\section{Consent of publish}

Not applicable.

\section{Ethical approval and consent to participate}

Ethical clearance was obtained from the Ethical Review Board of University of Gondar College of Medicine Institute of Public Health. Permission letter was obtained from Gondar town administration and the respective offices. The participants had the right to refuse or discontinue during participation at any time, the right to answer few or all questions was respected. Written informed consent was obtained from the head of the household before data collection and confidentiality and privacy of the respondent was maintained.

\section{Funding}

This research was sponsored by the principal investigator (self).

\section{Publisher's Note}

Springer Nature remains neutral with regard to jurisdictional claims in published maps and institutional affiliations.

\section{Received: 2 February 2019 Accepted: 13 March 2019}

Published online: 19 March 2019

\section{References}

1. Organization $\mathrm{WH}$ : The Role of the pharmacist in self-care and selfmedication: report of the 4th WHO Consultative Group on the Role of the Pharmacist, The Hague, The Netherlands, 26-28 August 1998. Geneva: World Health Organization; 1998. http://www.who.int/iris/handle/10665 165860

2. Sherazi BA, Mahmood KT, Amin F, Zaka M, Riaz M, Javed A. Prevalence and measure of self medication: a review. J Pharm Sci Res. 2012;4(3):1774.

3. Panda A, Pradhan S, Mohapatra G, Mohapatra J. Drug-related problems associated with self-medication and medication guided by prescription: a pharmacy-based survey. Indian J Pharmacol. 2016;48(5):515.

4. Fainzang S. Managing medicinal risks in self-medication. Off J Int Soc Pharmacovig. 2014;37(5):333-42.

5. Ruiz ME. Risks of self-medication practices. Curr Drug Saf. 2010;5(4):31523. https://doi.org/10.2174/157488610792245966.

6. Bennadi D. Self-medication: a current challenge. J Basic Clin Pharm. 2014;5(1):19-23. https://doi.org/10.4103/0976-0105128253.

7. da Silva Pons E, Knauth DR, Vigo Á, Mengue SS. Predisposing factors to the practice of self-medication in Brazil: results from the National Survey on Access, Use and Promotion of Rational Use of Medicines (PNAUM). PLOS ONE. 2017;12:12. https://doi.org/10.1371/journal.pone.0189098.

8. Sanghani $\mathrm{S}$, Zaveri $\mathrm{H}$, Patel V. Self medication: prevalence and pattern in urban community. J Pharmacovig Drug Saf. 2008;5:95-8.

9. Phalke V, Phalke D, Durgawale P. Self-medication practices in rural Maharashtra. Indian J Commun Med. 2006;31 (1):34-5. http://www.ijcm.org.in/ text.asp?2006/2031/2001/2034/54933.

10. Al Akshar SA, Shamssain M, Metwaly Z. Pharmacists perceptions of community pharmacy practice in UAE: an Overview. IOSR J Pharm. 2014;4(6):47-56.

11. Suleiman AK. Self-medication and the advisory role of pharmacists in Riyadh, Saudi Arabia. Arch Pharm Pract. 2013:4(4):180-6.

12. Ayalew MB. Self-medication practice in Ethiopia: a systematic review. Patient pref Adher. 2017:11:401-13.
13. Pagan JA, Ross S, Yau J, Polsky D. Self-medication and health insurance coverage in Mexico. Health Policy. 2006;75(2):170-7. https://doi. org/10.1016/j.healthpol.2005.1003.1007.

14. Khan SJ, Amanullah KS, Shah N. Self-medication with antibiotics in urban areas of Peshawar. Gomal J Med Sci. 2011:9(1):1-4

15. Osemene K, Lamikanra A. A study of the prevalence of self-medication practice among university students in Southwestern Nigeria. Trop J Pharm Res. 2012;11(4):683-9. https://doi.org/10.4314/tjpr.v43111i4314 .4321.

16. Centers for Disease Control and Prevention (CDC): antibiotic resistance threats in the United States. 2013. http://www.cdc.gov/drugresistance/ threat-report-2013/pdf/ar-threats-2013-508. Accessed 24 May 2013.

17. Chang FR, Trivedi K. Economics of self-medication: theory and evidence. Health Econ. 2003;12(9):721-39.

18. Abula T, Worku A. Self-medication in three towns of North West Ethiopia. EJHD. 2017:15:1

19. Abay S, Amelo W. Assessment of Self-medication practices among medical, pharmacy, health science students in Gondar University, Ethiopia. J Young Pharm. 2010;2(3):306-10.

20. Gutema GB, Gadisa DA, Kidanemariam ZA, Berhe DF, Berhe AH, Hadera MG, Hailu GS, Abrha NG. Self-medication practices among health sciences students: the case of Mekelle University. J Appl Pharm Sci. 2011;1(10):183.

21. Beyene A, Getachew E, Doboch A, Poulos E, Abdurahman K. Knowledge, attitude and practice of self medication among pharmacy students of rift Valley University, Abichu campus, Addis Ababa, Ethiopia. J Health Med Informat. 2017:8(269):2.

22. Shankar P, Partha P, Shenoy N. Self-medication and non-doctor prescription practices in Pokhara valley, Western Nepal: a questionnaire-based study. BMC Fam Pract. 2002;3(1):17.

23. Hsiao F-Y, Lee J-A, Huang W-F, Chen S-M, Chen H-Y. Survey of medication knowledge and behaviors among college students in Taiwan. Am J Pharm Educ. 2006;70(2):30.

24. Zafar SN, Syed R, Waqar S, Zubairi AJ, Vaqar T, Shaikh M, YousafW, Shahid S, Saleem S. Self-medication amongst university students of Karachi: prevalence, knowledge and attitudes. J Pak Med Assoc. 2008;58(4):214.

25. Al Flaiti M, Al Badi K, Hakami WO, Khan SA. Evaluation of self-medication practices in acute diseases among university students in Oman. J Acute Dis. 2014;3(3):249-52.

26. Kassie AD, Bifftu BB, Mekonnen HS. Self-medication practice and associated factors among adult household members in Meket district, Northeast Ethiopia, 2017. BMC Pharmacol Toxicol. 2018;19(1):15.

27. Sado E, GedifT. Drug utilization at household level in Nekemte Town and surrounding rural areas, western Ethiopia: a cross-sectional study. Open Access Lib J. 2014;1(03):1.

28. Selvaraj K, Kumar SG, Ramalingam A. Prevalence of self-medication practices and its associated factors in Urban Puducherry, India. Persp Clin Res. 2014;5(1):32.

29. Alghanim S. Self-medication practice among patients in a public health care system/Pratique de l'automédication chez les patients bénéficiant d'un système de soins de santé public. East Mediter Health J. 2011;17(5):409-17.

30. Jalilian F, Mehdi Hazavehei S, Vahidinia AA, Jalilian M, Moghimbeig A Prevalence and related factors for choosing self-medication among pharmacies visitors based on health belief model in Hamadan Province, west of Iran. J Res Health Sci. 2013;13(1):81-5.

31. Mamo S, Ayele Y, Dechasa M. Self-medication practices among community of harar city and its surroundings, Eastern Ethiopia. J Pharm. 2018;2018:1. https://doi.org/10.1155/2018/2757108.

32. Fernando A, Bandara L, Bandara H, Pilapitiya S, Silva AD. A descriptive study of self-medication practices among Sri Lankan national level athletes. BMC Res Notes. 2017;10(1):257. https://doi.org/10.1186/s1310 4-13017-12579-13108.

33. Sajith M, Suresh SM, Roy NT, Pawar D. Self-medication practices among health care professional students in a tertiary care hospital, Pune. Open Public Health J. 2017;10:1.

34. Lukovic JA, Miletic V, Pekmezovic T, Trajkovic G, Ratkovic N, Aleksic D, Grgurevic A. Self-medication practices and risk factors for self-medication among medical students in Belgrade, Serbia. PloS one. 2014;9:12. https:// doi.org/10.1371/journal.pone.0114644). 
35. Garofalo L, Di Giuseppe G, Angelillo IF. Self-medication practices among parents in Italy. Biomed Res Int. 2015;2015:8. https://doi. org/10.1155/2015/580650.

36. Keshari SS, Kesarwani P, Mishra M. Prevalence and pattern of selfmedication practices in rural area of Barabanki. Indian J Clin Pract. 2014;25(7):636-9.

37. Kumar V, Mangal A, Yadav G, Raut D, Singh S. Prevalence and pattern of self-medication practices in an urban area of Delhi, India. Med J Dr DY Patil Univ. 2015;8(1):16.

38. Okyay RA, Erdoğan A. Self-medication practices and rational drug use habits among university students: a cross-sectional study from Kahramanmaraş, Turkey. PeerJ. 2017;5:e3990.

39. Ali AN, Kai JTK, Keat CC, Dhanaraj S. Self-medication practices among health care professionals in a Private University, Malaysia. Int Curr Pharm J. 2012;1(10):302-10.

40. Kajeguka DC, Moses E. Self-medication practices and predictors for self-medication with antibiotics and antimalarials among community in Mbeya City, Tanzania. Tanz J Health Res. 2017;19:4.

41. Patil SB, Vardhamane S, Patil B, Santoshkumar J, Binjawadgi AS. Kanaki AR: self-medication practice and perceptions among undergraduate medical students: a cross-sectional study. JCDR. 2014;8(12):HC20.
42. Helal R, Abou-ElWafa H. Self-medication in university students from the city of Mansoura, Egypt. J Environ Public Health. 2017;2017:7. https://doi. org/10.1155/2017/9145193.

43. Divya M, Bharatesh S, Vasudeva G, Varalakshmi C. Self-Medication Among Adults in Urban Udupi Taluk, Southern India. Int J Med Public Health. 2016;6(3):126-9.

44. Wen Y, Lieber E, Wan D, Hong Y. Group NCHSPT: a qualitative study about self-medication in the community among market vendors in Fuzhou, China. Health Soc Care Community. 2011;19(5):504-13.

45. Ocan M, Bwanga F, Bbosa GS, Bagenda D, Waako P, Ogwal-Okeng J, Obua C. Patterns and predictors of self-medication in northern Uganda. PLoS ONE. 2014;9:3. https://doi.org/10.1371/journal.pone.0092323).

46. Abdulraheem I, Adegboye A, Fatiregun A. Self-medication with antibiotics: empirical evidence from a Nigerian rural population. Br J Pharm Res. 2016;11(5):1-3
Ready to submit your research? Choose BMC and benefit from:

- fast, convenient online submission

- thorough peer review by experienced researchers in your field

- rapid publication on acceptance

- support for research data, including large and complex data types

- gold Open Access which fosters wider collaboration and increased citations

- maximum visibility for your research: over $100 \mathrm{M}$ website views per year

At BMC, research is always in progress.

Learn more biomedcentral.com/submissions 